\title{
DLEU1 wt Allele
}

National Cancer Institute

\section{Source}

National Cancer Institute. DLEU1 wt Allele. NCI Thesaurus. Code C54434.

Human DLEU1 wild-type allele is located in the vicinity of $13 q 14.3$ and is approximately 23 $\mathrm{kb}$ in length. This allele, which encodes leukemia-associated protein 1 , is involved in tumor suppression. Frequently, the allele has been found to be deleted in chronic lymphocytic leukemia. 